\title{
Pain relief as a way to legitimate human rights
}

\section{O alívio da dor como forma de legitimação dos direitos humanos}

\author{
Lívia Vieira Lisboa ${ }^{1}$, José Augusto Ataíde Lisboa ${ }^{2}$, Katia Nunes Sáa
}

DOI 10.5935/1806-0013.20160014

\section{ABSTRACT}

BACKGROUND AND OBJECTIVES: Chronic pain is a complex and multidimensional problem with consequences for its appreciation in different social segments. It is necessary to understand how human rights may provide basis for political health actions on the subject. This study aimed at evaluating how the legitimation of human rights to the access to chronic pain management is being dealt with.

CONTENTS: Research tools were literature review and documental analysis. Due to the qualitative model used, we decided to follow recommendations of the Standards for Reporting Qualitative Research, available in http://www.ncbi. nlm.nih.gov/pubmed/24979285. Data were collected via Internet and statements, legislations and conferences related to human rights and health in chronic pain were included. Data were compared to national and international health policies, involving data from the Department of Health database. After analysis of human rights health promotion documents, we have identified that the Declaration of Montreal of 2010, developed by the International Association for the Study of Pain, has the foundations for political actions to manage and control chronic pain. Notwithstanding the participation of Brazil in support to this Declaration, there are still few concrete actions to implement strategies proposed by the model. We have also identified the major socio-economic impact of chronic pain on Brazilian contemporary society.

CONCLUSION: Chronic pain should be studied and managed as a public health problem and health policies need to support this human right with further efficiency.

Keywords: Chronic pain, Human rights, Right to health.

\footnotetext{
1. Universidade Católica de Salvador, Programa de Família na Sociedade Contemporânea, Salvador, BA, Brasil.

2. Universidade Federal da Bahia, Salvador, BA, Brasil.

3. Universidade Católica do Salvador, Salvador, BA, Brasil.

Submitted in September 15, 2015.

Accepted for publication in January 22, 2016.

Conflict of interests: none - Sponsoring sources: none.

Correspondence to:

Lívia Vieira Lisboa

Av. Cardeal da Silva, 205 - Federação

40231-902 Salvador, BA, Brasil.

E-mail: liviavieiralisboa@gmail.com

(C) Sociedade Brasileira para o Estudo da Dor
}

\section{RESUMO}

JUSTIFICATIVA E OBJETIVOS: A dor crônica é um fenômeno complexo e multidimensional, com consequências para sua valorização nos diferentes segmentos sociais. Faz-se necessário compreender como os direitos humanos podem fornecer bases para as ações políticas de saúde no tema. O objetivo deste estudo foi estudar como tem sido tratada a legitimação do direito humano do acesso ao tratamento da dor crônica.

CONTEÚDO: Utilizou-se revisão de literatura e análise documental. Devido ao modelo qualitativo empregado, optou-se por seguir as recomendaçōes do Standards for Reporting Qualitative Research, disponível em http://www.ncbi.nlm.nih.gov/ pubmed/24979285. A coleta de dados foi realizada pela internet e foram incluídas declaraçôes, legislaçôes e conferências relacionadas ao tema de direitos humanos e de saúde na dor crônica. Os dados obtidos foram confrontados com as políticas nacionais e internacionais de saúde, envolvendo dados obtidos da base de dados do Ministério da Saúde. Após a análise dos documentos de direitos humanos de promoçáo à saúde, identificou-se que a Declaração de Montreal de 2010, elaborada pela International Association for the Study of Pain, apresenta os fundamentos para açōes políticas para o tratamento e controle da dor crônica. Apesar da participação do Brasil no apoio a essa Declaraçáo, ainda existem poucas açôes concretas para implementaçáo das estratégias propostas no modelo. Identificou-se também o elevado impacto socioeconômico da dor crônica para a sociedade contemporânea brasileira.

CONCLUSÁO: A dor crônica deve ser estudada e tratada como um problema de saúde pública e as políticas de saúde precisam respaldar com maior eficiência esse direito humano.

Descritores Direito à saúde, Direitos humanos, Dor Crônica.

\section{INTRODUCTION}

Pain itself is difficult to be understood, diagnosed and treated. The Portuguese Association for the Study of Pain (APED), together with the Public Prosecutors Office of Portugal and the National Health Direction, has published a guideline defining pain as the fifth vital sign and bringing its ways of perception, identification and possibility of treatment ${ }^{1}$.

Pain sensation differs from person to person, even when there are similar features and conditions ${ }^{2}$. This is due to the subjective character of painful sensations, to biological responses variations and to attitudes in face of pain, difficulties with evaluation tools, lack of biological markers, subjectivity of examiners when interpreting signs and symptoms, and bio- 
psychosocial interactions ${ }^{3-7}$. So, pain is a complex and multidimensional phenomenon requiring interdisciplinary and intersectorial attention and care ${ }^{1,7,8}$.

Although in acute conditions pain is a transient and physiological symptom useful for survival and related to noxious causal agents, when evolving to chronic state it becomes a morbidity by itself and affects large part of the world population, with prevalence from 12 to $55 \% \%^{3,5}$. In Brazil, it is estimated that more than $40 \%$ of the population has chronic pain ${ }^{4,6,9}$, which requires more than just public health actions, and its treatment and relief should be understood as Human Rights legitimation ${ }^{8,10-12}$.

In the perspective of the Right to Health, integral part of Social Rights, which is part of Fundamental Rights, it is necessary that member States protect people with regard to their basic needs ${ }^{13,14}$. The need to promote health in the domain of chronic pain has to generate positive impacts on quality of life and social participation of people affected by it ${ }^{8}$. Most Brazilian studies on chronic pain were developed in the disciplinary field, generating a gap on the intersectorial side of the problem, especially involving Human Rights ${ }^{15}$.

This study aimed at investigating how the legitimation of the human right to access to chronic pain treatment in Brazil is being dealt with.

\section{CONTENTS}

This qualitative study has observed the 21 specific items of the Standards for Reporting Qualitative Research (SRQR) ${ }^{16}$, used for qualitative research (available at http://www.ncbi.nlm. nih.gov/pubmed/24979285). Literature was reviewed as from a search in open journals and Pubmed, Scielo and LILACS databases, and complemented by Institutional Repositories (theses and dissertations databases), using keywords "pain", "chronic pain", "human rigths", "dor", "dor crônica", "direitos humanos", without time and/or language restriction. We have looked for scientific works in the International Association for the Study of Pain (IASP), the Portuguese Association for the Study of Pain (APED) and the Brazilian Association for the Study of Pain (SBED) websites.

Interdisciplinarity among health and Law areas authors has laid the basis for the building of this model, which allowed evaluation by triangulation of methods, which may be defined as "[...] a systematic process of asking questions about the merit and relevance of a certain subject, proposal or program" ${ }^{17}$. After reviewing the literature in search for concepts and the importance of the study of pain as a human fundamental right, authors carried out the preliminary documental analysis ${ }^{18-20}$ of identified documents, including characteristics of data, historic context and importance of selected documents theme, with regard to health, provided by Human Rights.

We have studied some documents which, along Humans Rights history, promote the Right to Health of any nature, for then getting to those effectively addressing pain treatment as legitimation of Human Rights. After analysis and classifica- tion by means of systematic reading, we tried to understand Human Rights protection with regard to Right to Health. Articles establishing such objective were highlighted and placed in a table in Microsoft Word document.

We have compared items recommended by the Declaration of Montreal, identified as the best applicable document to the objective of our study, with health policies adopted for individuals with chronic pain in Brazil. Triangulation was made as from the comparison between documents and data acquired by DATASUS (available at http://www2.datasus.gov.br/DATASUS/index.php?area $=01)^{16,21}$. To make feasible such documental analysis, two stages were completed: the first, based on content search and review of the document; the second using documents interpretation criteria ${ }^{17,18,20,21}$, observing gaps deserving practical actions for their implementation.

DATASUS data ${ }^{21}$, obtained as from the TABENET system (available at: http://www2.datasus.gov.br/DATASUS/index. php?area $=02$ ) and the National Health Estimate Research (PNES) were selected by sampling, observing the estimated percentage of limitations in the body region most affected by chronic pain in the country - the spine. Characteristics by country region in urban zone were observed, regardless of gender, color, race and social class, aiming at effectively correlating by triangulation of methods, the theoretical referential and the documental analysis by sampling.

To get to table 1 , we have identified the information access item in the DATASUS portal and, when clicking on the TABENET system, the system itself brings some options of available data for tabulation: health indicators and pacts; health assistance; epidemiology and morbidities; healthcare network; vital, demographic and socioeconomic statistics; queries and researches; complementary health; TABENET access statistics and tutorial.

So, we have chosen queries and researches indicator, as well as "module Q", chronic diseases module (for being the object of our study), where the following items were identified for tabulation: arthritis/rheumatism, chronic spinal problem, job-related musculoskeletal disorders (DORT), depression and other mental problems. In addition, we have refined the search selecting indicators of "region" and "urban situation", as well as "non-active" situations in the spine and " $\%$ of severe limitation by spinal problem" as content. Data are from 2013, because this was the only available period.

Preliminary analysis allowed the identification of the following documents related to the subject: Declaration of Human Rights (1948) ${ }^{22}$, International Convention of Economic, Social and Cultural Rights - Protocol of San Salvador (1966) ${ }^{23}$, Treaty on Intellectual Property Rights Regarding Trade (TRIPS) $(1994)^{24}$, International Conference on Human Rights $(1993)^{25}$ and the Declaration of Montreal $(2010)^{26}$. From these documents, it was identified that the Declaration of Montreal (2010) should be submitted to deeper documental analysis to understand how and why the access to pain control is a Fundamental Human Right. It was observed that the Declaration of Montreal specifically addresses the right to access to pain treatment, in articles 1, 2 and 3 (Table 1). 
Table 1. Documents of human rights for health promotion

\begin{tabular}{|c|c|c|c|}
\hline Human and health rights & Year of document & Articles & Rights to health in which perspective \\
\hline Decree of human rights & 1948 & $3^{\circ}, 8^{\circ}$ & Life, drugs \\
\hline Protocol of San Salvador & 1966 & $10^{\circ}$ & Enjoy health, public asset \\
\hline TRIPS & 1994 & - & Intellectual property \\
\hline International Conference of Human Rights & 1993 & $12^{\circ}$ & Implementation of public policies \\
\hline Decree of Montreal & 2010 & $1^{\circ}, 2^{\circ} \& 3^{\circ}$ & Access to pain treatment \\
\hline
\end{tabular}

TRIPS = Aspects of Intellectual Property Rights Regarding Trade.

In analyzing DATASUS 2013 data, in the chronic diseases module involving painful conditions such as arthritis, rheumatism, chronic spinal problems and DORT, according to CID10, the percentage of severe limitation is increased by problems especially affecting spine. It was observed that $15.7 \%$ of the Brazilian population suffer limitation by severe pain, being more frequent in the Mid-West (20.8\%), followed by Northeast, South and North, with lowest percentage in the Southeast, with $13.4 \%$ (Table2).

Table 2. Severe limitation caused by spinal pain by region

\begin{tabular}{lcc}
\hline Regions & $\begin{array}{c}\text { \% severe } \\
\text { limitation spine }\end{array}$ & Statistical information \\
\hline 1. North & 15.7 & $\mathrm{Cl}=(12.3-19.1) ; \mathrm{CV}=11.2 \%$ \\
2. Northeast & 17.5 & $\mathrm{Cl}=(15.0-20.0) ; \mathrm{CV}=7.3 \%$ \\
3. Southeast & 13.4 & $\mathrm{Cl}=(11.3-15.5) ; \mathrm{CV}=8.1 \%$ \\
4. South & 16.7 & $\mathrm{Cl}=(13.9-19.6) ; \mathrm{CV}=8.6 \%$ \\
5. Mid-West & 20.8 & $\mathrm{Cl}=(17.2-24.3) ; \mathrm{CV}=8.8 \%$ \\
Total & 15.7 & $\mathrm{Cl}=(14.4-17.0) ; \mathrm{CV}=4.1 \%$ \\
\hline
\end{tabular}

$\%$ of severe limitation by spinal problem by Region, Situation: Urban, Period: 2013.

IBGE - Brazilian Institute of Geography and Statistics; PNS 2013 - National Health Research;

PNS - Chronic diseases module - arthritis/rheumatism, chronic spinal problem, DORT - job-related musculoskeletal disorders, depression and other mental problems.

Questions of this module were applied to one dweller in each home, selected among those with 18 years of age or above.

For being a sample research, indicator value may not have statistical significance when separated for specific population segments, such as Indians, Yellow and Black people, because these groups are very small in some states and regions.

At international level, studies show that world prevalence varies from 15 to $55 \%$ and is more frequent in less developed countries 5 . One out of three affected people is unable to have independent life ${ }^{3}$.

Articles of the Declaration of Montreal of 2010 were compared to epidemiological data at national and international levels. It was observed that such declaration is the health-related Document which effectively defines the access to specific treatment to control and relieve chronic pain as a human right.

\section{DISCUSSION}

Analyzing how the legitimation of the human right to access to chronic pain treatment in Brazil is being dealt with, it was observed that epidemiological data point to the fact that rec- ommendations of the Declaration of Montreal of 2010, which recommend chronic pain treatment as a public health problem, lack more precise actions for the effective control of the problem. The Declaration of Montreal was developed by delegate countries of the International Pain Summit (IPS) affiliated to IASP ${ }^{26}$. Such organization has more than 129 institutions in different countries which study pain, especially chronic pain, understanding the need to observe its effects on people's lives in the financial, family and emotional context, as well as to study ways of relieving and controlling pain symptoms, always looking for the impact on quality of life of patients ${ }^{8}$. However, in spite of Brazil's participation in the support to this declaration, there are still few concrete national actions to comply with its articles.

Brazil has approximately $40 \%$ of the population living with chronic pain, as shown by studies in Salvador, Maranhão and Sáo Paulo ${ }^{4,6,9}$. Raw epidemiological data of the Brazilian Institute of Geography and Statistics and DATASUS reflect clear subnotifications for being obtained by sampling as from the interview of just one dweller in each drawn home, aged equal to or above 18 years, without distinction of gender, age group, color or race or whether the population is urban or rural $^{21}$. So, the problem of lack of assistance is even more severe than one could imagine. These findings show that if public health policies were based on IBGE and DATASUS data rather than on epidemiological studies, actions would be inadequate to control the problem.

In addition to psychological and physiological factors ${ }^{4,7,12}$, chronic pain patients also have socioeconomic problems ${ }^{8}$, with further difficulties to work, both physically and intellectually, and high drug and procedure costs. The promotion of pain as a public health problem is the first step for its legitimation. The attempt to control and treat chronic pain exclusively addressing clinical and biological aspects does not support IASP recommendations for not contemplating public health policies, health economics and human rights ${ }^{2,3,8}$.

The Declaration of Montreal is a document to guide healthcare professionals and public managers in terms of specific health promotion actions. Its article 3 establishes that all people with pain have the right to adequate access to its treatment, receiving adequate professional assistance ${ }^{26}$. This, alone, has two perspectives: the first is the access to pain treatment, and the second is the adequate treatment. This Declaration also states that the lack of pain control treatment or the lack of access to treatment should be considered as torture, cruel act, inhuman act and/or degrading treatment ${ }^{26}$. This means that the absence of chronic pain treatment is equivalent to torture and other degrading acts against human beings provided by the Univer- 
sal Declaration of Human Rights (1948) ${ }^{22}$.

The Pain Management Guide ${ }^{27}$ proposed by the Brazilian and Portuguese Societies for the Study of Pain (SBED and APED) has established some guidelines for chronic pain treatment. Among them there are recommendations to address chronic low back pain as from well grounded functional classifications. However, few guides are available for the approach of different chronic painful syndromes. This is because there are still limited evidences to support decision-making processes and investments on health. This document identifies two major causes of low back pain: lifestyle and industrialization. It is interesting to note that economic rights are legitimated by capitalist forces themselves; however, the right to health is still not legitimated ${ }^{3-7,9}$. This confirms the need to legitimate care of chronic pain patients starting with the principle of dignity of human beings ${ }^{28}$.

In this perspective, the National Program for Assistance to Pain and Palliative Care, created by Ordinance $19 / 2002^{29}$, provides for the creation in the Single Health System (SUS) Reference Centers for Chronic Pain treatment, which has then resulted in Ordinance GM/MS 1219 from July 23, 2002 ${ }^{30}$. To comply with such resolution, in addition to other factors, it was considered "the duty to assure to chronic pain patients all citizenship rights, the protection of their dignity, their wellbeing, right to life and access to pain treatment and, especially access to opioids", on part of the State represented by SUS. At this point, it is worth observing that such ordinance addresses adequate treatment, protecting patients' dignity, thus legitimating, at least by means of official documents, the need for adequate assistance as a way to promote health and legitimate fundamental human rights. However, there is a large gap between what is proposed and what is achieved.

Our study was limited by the lack of accurate epidemiological data from national information systems about chronic pain, which makes difficult the comparison with other countries. In addition, documental analysis was limited by the scarcity of legal tools on the subject in Brazil. These factors show the magnitude of subnotifications and lack of attention to the problem, which is reflected in the lack of legitimation at national level of the right to chronic pain relief.

The Declaration of Montreal is the only document treating pain as a public health problem and points as a need for IASP Member-States the promotion of public policies so that everyone has access not only to treatment, but to adequate treatment. The access to chronic pain treatment and relief legitimates the dignity of human beings ${ }^{11,28}$.

Legitimation is linked to the notion of public authorities control, since society has "mechanisms of participation, safety and independence (not only domination)" 14 of social promotion. The efficacy of the Declaration of Montreal to legitimate the principle of dignity of human beings ${ }^{28}$ opens space, within Brazilian laws, for the legitimation of Rights to Health in the domain of chronic pain. Respecting the Universal Declaration of Human Rights, it is paramount that the access to prevention, to effective treatment and to rehabilitation within and for society is legitimated.

\section{REFERENCES}

1. Circular Normativa de No 09/DGCG e Data: 14/06/2003. A Dor como $5^{\circ}$ sinal vital. Registo sistemático da intensidade da Dor. Disponível em: http://www.aped-dor.org/ index.php/sobre-a-dor/a-dor-como-5-sinal-vital.

2. Bell WE. Dores Orofaciais. Classificação, Diagnóstico, Tratamento. $3^{\mathrm{a}}$ ed. São Paulo: Quintessence; 1991.

3. Breivik H, Collett B, Ventafridda V, Cohen R, Gallacher D. Survey of chronic pain in Europe: prevalence, impact on daily life, and treatment. Eur J Pain. 2006;10(4):287-333.

4. Sá KN, Baptista AF, Matos MA, Lessa I. Chronic pain and gender in Salvador population, Brazil. Pain. 2008;139(3):498-506.

5. Johannes CB, Le TK, Zhou X, Johnston JA, Dworkin RH. The prevalence of chronic pain in United States adults: results of an Internet-based survey. J Pain. 2010;11(11):1230-9.

6. Dellaroza MS, Pimenta CA, Duarte YA, Lebrăo ML. [Chronic pain among elderly residentes in São Paulo, Brazil: prevalence, characteristics, and association with functional capacity and mobility (SABE) Study]. Cad Saude Publica, 2013;29(2):325-34. Portuguese.

7. McCall-Hosenfeld JS, Winter M, Heeren T, Liebschutz J. The association of interpersonal trauma with somatic symptom severity in a primary care population with chronic pain: exploring the role of gender and the mental health sequelae of trauma. J Psychosom Res. 2014;77(3):196-204.

8. Fishman SM. Recognizing pain management as a human right: a first step. Anesth Analg. 2007;105(1):8-9.

9. De Moraes Vieira EB, Garcia JB, da Silva AA, Mualem Araújo RL, Jansen RC. Prevalence, characteristics, and factors associated with chronic pain with and without neuropathic characteristics in São Luís, Brazil. J Pain Symptom Manage. 2012;44(2):239-51.

10. Comparato, FK. A afirmaçấo histórica dos direitos humanos. 6a ed. São Paulo: Saraiva; 2008.

11. Brennan F, Carr DB, Cousins M. Pain management: a fundamental human right Anesth Analg. 2007;105(1):205-21.

12. Van Hecke O, Torrance N, Smith BM. Chronic pain epidemiology and its clinical relevance. Br J Anaesth, 2013;111(1):13-8

13. Herkenhoff; J.P. Curso de Direitos Humanos, Gênese dos Direitos Humanos, Vol. 01 Editora Acadêmica: São Paulo; 1994. 21-32p.

14. Queiroz, C. Direitos Fundamentais: Funçôes, âmbito, conteúdo, questốes interpretativas e justiciabilidade. Coimbra Editora: Coimbra; 2006. 25-8p.

15. Leão ER, Aquarone RL, Rother ET. Pain research: bibliometric analysis of scientific publications of a Brazilian Research Institution. Rev Dor. 2013;14(2)94-9.

16. O'Brien BC, Harris IB, Beckman TJ, Reed DA, Cook DA. Standards for reporting qualitative research: a synthesis of recommendations. Acad Med. 2014;89(9):1245-51.

17. Minayo, MC. Conceito de avaliaçấo por triangulaçấo e métodos, in: Avaliaçấo por triangulação e métodos: abordagens de programas sociais. Rio de Janeiro: Editora Fiocruz; 2005. 11-53p.

18. Souza J, Karantorski LP, Luis M. Análise documental e observaçâo participante na pesquisa em saúde mental. Rev Baiana Enferm. 2011;25(2):221-8.

19. Sá-Silva JR, Almeida CD, Guindani JF. Pesquisa documental: Pistas Teóricas e Metodológicas. Revista Brasileira de História \& Ciências Sociais. Ano I - Número I - Julho de 2009. Disponível em: http://www.unisc.br/portal/upload/com_arquivo/pesquisa_documental_pistas_teoricas_e_metodologicas.pdf.

20. Spink MJ, (org). Práticas Discursivas e Produçáo de sentidos no Cotidiano: Aproximaçôes teóricas e metodológicas. $3^{\mathrm{a}}$ ed. São Paulo: Cortez Editora; 2004. 123-51p.

21. Instituto Brasileiro de Geografia e Estatística, IBGE. Pesquisa Nacional de Saúde, 2013. Participação do Estado de Saúde, estilos de Vida e Doenças Cônicas: Brasil, grandes Regiōes e Unidades da Federação. Ministério da Saúde: Departamento de análise de situação da saúde. FIOCRUZ, 2013. 48-50p.

22. Declaração Universal dos Direitos Humanos (1948). UNIC - Rio/005 - Agosto, 2009 Disponível em: http://www.dudh.org.br/wp-content/uploads/2014/12/dudh.pdf.

23. Convenção Internacional de Direitos Econômicos, Sociais e Culturais - Protocolo de São Salvador (1966). Disponível em: http://www.cidh.oas.org/basicos/portugues/e. Protocolo_de_San_Salvador.htm.

24. Acordo sobre os Aspetos de Direitos de Propriedade Intelectual Concernente ao Comércio - TRIPS (1994). Disponível em: http://www.nedac.com.br/pdf/ac_trips.pdf.

25. Conferência Mundial de Direitos Humanos - CMDH (1993). Disponível em: http:// www.pge.sp.gov.br/centrodeestudos/bibliotecavirtual/instrumentos/viena.htm.

26. Declaração de Montreal (2010). Disponível em: http://www.iasp-pain.org/Advocacy/ Content.aspx? ItemNumber $=1821$ \&navItemNumber $=582$.

27. Guia Para o Tratamento da Dor em Contextos de Poucos Recursos. Material educativo escrito por uma equipe de autores multidisciplinar e multinacional, para distribuição geral aos prestadores de cuidados de saúde. IASP - Intenational Association of Study of Pain. Disponível em: file://C:/Users/JoseAugusto/Downloads/GuidetoPainManagement_Portuguese.pdf.

28. Sarlet IW. As dimensôes da dignidade da pessoa humana: construindo uma compreensão jurídico-constitucional necessária e possível. In: Dimensôes da Dignidade: Ensaio de Filosofia do Direito e Direito Constitucional. 2a ed. Revisada e Ampliada. Porto Alegre: Livraria do Advogado Editora; 2013. 15-30p.

29. Portaria GM n. ${ }^{\circ} 19$ de 03 de janeiro de 2002. Disponível em: http://ftp.rgesus.com $\mathrm{br} /$ legislacoes $/ \mathrm{gm} / 8214-19 . \mathrm{html}$ ?q=.

30. Portaria GM/MS no 1.319 de 23 de julho de 2002. Disponível em: http://www.husm. ufsm.br/janela/legislacoes/centros-tratamento-dor/centros-tratamento-dor/portaria-gmms-no-1319-de-23-de-julho-de-2002.pdf 